\title{
Environment and medium volume influence in vitro fertilisation of pig oocytes
}

\author{
P. Coy' ${ }^{1}$ E. Martínez ${ }^{2}$, S. Ruiz', J.M. Vázquez ${ }^{2}$, J. Roca ${ }^{2}$ and J. Gadea ${ }^{2}$ \\ University of Murcia, Murcia, Spain
}

\section{Summary}

Oviductal oocytes $(n=795)$ were obtained from ovulation-induced prepubertal gilts. In the first experiment, different parameters related to in vitro fertilisation (IVF) were compared in the presence and absence of cumulus matrix (which is shed with the oocytes at ovulation.) The results show that the presence of this matrix is beneficial because the rates of fertilisation $(69 \%)$ and monospermy (number of monospermic oocytes/total number of healthy mature oocytes; $42 \%$ ), and the median number of spermatozoa per oocyte $(1.52 \pm 0.06)$, were improved with respect to those obtained in its absence $(54 \%$, $22 \%$ and $2.33 \pm 0.08$, respectively; $p<0.01$ ). In the second experiment the effect of two different volumes of co-incubation medium $(2 \mathrm{ml}$ and $0.4 \mathrm{ml})$ on the same parameters of porcine IVF were compared. No significant differences between volumes were observed, except in the mean number of spermatozoa per oocyte and the percentage of dispermic oocytes.

Keywords: Cumulus, In vitro fertilisation, Medium volume, Porcine

\section{Introduction}

Successful in vitro fertilisation of pig eggs (offspring born) was first reported by Cheng et al. (1986). Subsequently, numerous workers have tried to improve the efficiency of in vitro fertilisation in the pig (Nagai $e t$ al., 1988; Mattioli et al., 1989; Nagai \& Moor, 1990; Park \& Pursel, 1991). Although fertilisation rates are extremely high (80-100\%), the probability of obtaining viable embryos is very low due to the high rate of polyspermic fertilisation.

In previous work, we studied the effect of coincubation time (Coy et al., 1993a) and sperm concentration (Coy et al., 1993b), observing that both factors have a significant influence on the results of pig IVF but are not the only factors.

The environment during IVF in pigs is quite differ-

All correspondence to: P. Coy, Departamento de Biología Animal (Fisiología Animal), Facultad de Veterinaria, Campus de Espinardo, Universidad de Murcia, Aptdo. 4021, Murcia E-30071, Spain. Fax: 34-68 305101.

${ }^{1}$ Department of Animal Biology, Veterinary Faculty, University of Murcia, Aptdo. 4021, Murcia E-30071, Spain.

${ }^{2}$ Department of Animal Pathology, Veterinary Faculty, University of Murcia, Aptdo. 4021, Murcia E-30071, Spain. ent from that of the oviduct (Mattioli et al., 1989). For example, in vivo, cumulus cells and intercellular matrix are present at least at the beginning of the oocyte's stay in the oviduct. The effect of the presence of cumulus cells on the results of IVF varies among species. In the rabbit and hamster cumulus cell removal had no effect on the proportion of eggs fertilised in vitro (Chang et al., 1971; Fraser et al., 1971; Miyamoto \& Chang, 1972). Removal of cumulus cells reduced the fertilisation rate of mouse eggs (Cross \& Brinster, 1970; Miyamoto \& Chang, 1972). Granulosa cells obtained from the follicular wall increased the fertilisation rate and decreased polyspermy of bovine oocytes (Fukui \& Ono, 1989). Cumulus cells influenced the maturation and penetrability of these oocytes also (Shioya et al., 1988). In pigs, cumulus cells may improve the rates of fertilisation, but no data are a vailable about the effects on monospermy (Kikuchi et al., 1991).

Another factor that may influence the results of IVF is the volume of co-incubation medium, with the confounding effects of sperm number and sperm concentration (Mattioli et al., 1989). Medium volume affected the rates of fertilisation and monospermy in rats (Niwa \& Chang, 1974).

The present studies were designed to evaluate the 
effects of cumulus cells and intercellular matrix (after exposure to the oviductal environment) and of medium volume on the efficiency of pig IVF.

\section{Materials and methods}

\section{Culture media}

Dulbecco's phosphate-buffered saline (PBSDm) supplemented with $4 \mathrm{mg} / \mathrm{ml}$ bovine serum albumin (BSA, fraction V; Sigma, St Louis, Mo.), $0.36 \mathrm{mM}$ pyruvate (Merck, Darmstadt, Germany), $5.5 \mathrm{mM}$ glucose (Merck) and $70 \mu \mathrm{g} / \mathrm{ml}$ kanamycin (Sigma) (Mattioli $e t$ al., 1988), pH 7.4, was used for flushing oviducts and manipulating oocytes. Sperm washing medium (SWM) was saline $(0.9 \% \mathrm{NaCl})$ containing $1 \mathrm{mg} / \mathrm{ml}$ BSA, pH 7.2 (Yanagimachi, 1981). Sperm capacitation medium (CM) was TCM 199 (Earle salts, Boehringer, Mannheim, Germany) supplemented with $12 \%$ heatinactivated fetal calf serum (Gibco, Grand Island, N.Y.), $0.91 \mathrm{mM}$ sodium pyruvate, $2.92 \mathrm{mM}$ calcium lactate (Merck) and $3.05 \mathrm{mM}$ glucose, pH 7.8 (Cheng et al., 1986). Fertilisation medium (FM) was prepared by adding $2 \mathrm{mM}$ caffeine (Merck) and $5.84 \mathrm{mM}$ calcium lactate to the CM (M. Mattioli, personal communication), pH 7.4.

\section{Oocyte recovery}

Large White $\times$ Landrace prepubertal gilts weighing $80-95 \mathrm{~kg}$ were injected intramuscularly with $1250 \mathrm{IU}$ pregnant mare serum gonadotrophin (PMSG; Intervet International, Boxmeer, Holland) followed $55 \mathrm{~h}$ later with 750 IU human chorionic gonadotrophin (hCG; Intervet). Freshly ovulated oocytes were obtained $42-46 \mathrm{~h}$ after $\mathrm{hCG}$ by flushing the oviducts during laparotomy as described by Coy (1992). A total of 795 oocytes were used. At the laboratory, the oocytes were washed twice in PBSDm $\left(39^{\circ} \mathrm{C}\right)$ and classified in two groups. In the first group we included all those oocytes that retained the cumulus cell matrix and in the second group we included all those oocytes that were accidentally denuded during transport or manipulation but were in the cumulus cell matrix when they were recovered. Hence, they were denuded for a short time between recovery and fertilisation. Ten to fifteen cumulus-intact or denuded oocytes were transferred to each Petri dish $(35 \times 10 \mathrm{~mm})$ containing FM at $39^{\circ} \mathrm{C}$ under $5 \% \mathrm{CO}_{2}$ in air. Both treatments were evaluated in each trial in experiment 1.

\section{Sperm capacitation}

Ejaculated boar spermatozoa were diluted immediately after collection, with a commercial extender preparation (MR-A; Martín et al., 1983), to a final concentration of $3 \times 10^{7}$ spermatozoa $/ \mathrm{ml}$. The diluted spermatozoa were incubated for about $24 \mathrm{~h}$ at $15^{\circ} \mathrm{C}$ (Cheng et al., 1986; Mattioli et al., 1989). Before use, the spermatozoa were centrifuged at $100 \mathrm{~g}$ for $3 \mathrm{~min}$ to remove seminal plasma clots and other heavy particles; the supernatant was recovered and washed three times by centrifugation at $1200 \mathrm{~g}$ for $3 \mathrm{~min}$. The first two times the pellet was resuspended in SWM, and the final pellet was resuspended by $2 \times 10^{8}$ spermatozoa $/ \mathrm{ml}$ in $3 \mathrm{ml} \mathrm{CM}$. Spermatozoa were incubated for $40-60 \mathrm{~min}$ at $39^{\circ} \mathrm{C}$ (Vázquez, 1991) in a tightly capped test tube. Only samples with progressive motility higher than $60 \%$ were used.

\section{In vitro fertilisation and examination of oocytes}

Experiment 1. A portion of the preincubated sperm suspension was added to the Petri dishes with FM containing the cumulus-intact or denuded oocytes so that the final concentration of spermatozoa at insemination was $6 \times 10^{5} \mathrm{cell} / \mathrm{ml}$. The medium volume was $2 \mathrm{ml}$ and the co-incubation time was $4 \mathrm{~h}$.

Experiment 2. After classification, only cumulusintact oocytes were used for this experiment. They were fertilised as in experiment 1 , but the medium volume was 0.4 or $2 \mathrm{ml}$. Each trial included both treatments.

After $4 \mathrm{~h}$ of co-incubation the oocytes from both experiment 1 and 2 were transferred to fresh FM and adherent spermatozoa and cumulus masses were removed from the zona pellucida by pipetting (Mattioli et al., 1989). Thereafter, the eggs were cultured for a further 12-14 $\mathrm{h}$. The oocytes were then washed and fixed as whole mounts in ethanol:acetic acid $(3: 1 \mathrm{v} / \mathrm{v})$ and stained in 1\% lacmoid $24 \mathrm{~h}$ later (Chang, 1952). The fertilisation rate and the incidence and degree of polyspermy were evaluated by phase contrast microscopy. Oocytes at germinal vesicle (GV) stage were classified as immature. Oocytes with a broken oolemma or abnormal appearance of the cytoplasm were classified as degenerated. Oocytes with pronuclei (normally one or two) without any sperm tail were considered activated.

Table 1 Effect of cumulus cell presence on fertilisation of in vivo matured pig oocytes

\begin{tabular}{|c|c|c|c|c|}
\hline $\begin{array}{l}\text { Type of } \\
\text { oocytes }\end{array}$ & $\begin{array}{l}\text { Oocytes } \\
\text { recovered }\end{array}$ & $\begin{array}{l}\text { Healthy } \\
\text { mature } \\
\text { oocytes } \\
(\%)\end{array}$ & $\begin{array}{l}\text { Fertilised } \\
\text { oocytes } \\
(\%)\end{array}$ & $\begin{array}{l}\text { Fertilisation } \\
\text { range }^{a}(\%)\end{array}$ \\
\hline Cumulus & 231 & $178(77.1)$ & $123(69.1)^{b}$ & $52-96$ \\
\hline Denuded & 282 & $203(72.0)$ & $109(53.7)^{b}$ & $13-82$ \\
\hline
\end{tabular}

a Variation in the percentage of fertilisation after six trials.

${ }^{b}$ Groups with the same superscript are different $(p<0.01)$. 
Table 2 Distribution of oocytes classified by the number of spermatozoa observed in the cytoplasm relative to the presence of cumulus cells

\begin{tabular}{|c|c|c|c|c|c|c|}
\hline \multirow{2}{*}{$\begin{array}{l}\text { Type of } \\
\text { oocytes }\end{array}$} & \multirow{2}{*}{$\begin{array}{l}\text { Healthy } \\
\text { mature } \\
\text { oocytes }\end{array}$} & \multirow{2}{*}{$\begin{array}{l}\mathrm{Spz} / \mathrm{oo}^{a} \\
(x \pm \mathrm{SEM})\end{array}$} & \multirow{2}{*}{$\begin{array}{l}\text { Monospermic } \\
\text { oocytes }^{b}(\%)\end{array}$} & \multicolumn{3}{|c|}{ Polyspermic oocytes $(\%)$} \\
\hline & & & & $2 \mathrm{spz}$ & $3 \mathrm{spz}$ & $>3 \mathrm{spz}$ \\
\hline Cumulus & 178 & $1.52 \pm 0.06^{c}$ & $75(42.1)^{c}$ & $38(21.3)^{d}$ & $6(3.4)$ & $4(2.2)^{b}$ \\
\hline Denuded & 203 & $2.33 \pm 0.08^{c}$ & $43(21.9)^{c}$ & $27(13.3)^{d}$ & $15(7.4)$ & $24(11.8)^{b}$ \\
\hline
\end{tabular}

Spz, spermatozoa; oo, oocyte.

${ }^{a}$ Relative to number of fertilised oocytes.

${ }^{b}$ As a percentage of the total number of healthy mature oocytes.

' Groups with the same superscript in the same column are different $(p<0.01)$.

${ }^{d}$ Groups with the same superscript in the same column are different $(p<0.05)$.

\section{Statistical analysis}

Percentages of fertilisation, monospermy and polyspermic oocytes $(2,3$ or $>3$ spermatozoa per oocyte) were analysed by chi-squared tests. The numbers of spermatozoa per oocyte were subjected to analysis of variance. Comparisons between means were made by paired $t$-test.

\section{Results}

\section{Experiment 1}

Cumulus-intact oocytes had higher rates of fertilisation, with the range being higher in every trial (Table 1). The percentage of activated oocytes ranged from $1.1 \%$ to $4.9 \%$ in both groups.

The percentage of monospermic oocytes was significantly higher $(p<0.01)$ when cumulus cells, intercellular matrix and any other molecules added in the oviduct were present (Table 2). Relative to the fertilised oocytes, $61.0 \%$ and $39.4 \%$ of cumulus-intact and denuded oocytes were monospermic. The percentages of polyspermic oocytes with $2(p<0.05)$ and more than $3(p<0.01)$ spermatozoa inside the vitellus were significantly higher in denuded than in cumulus-intact oocytes.

\section{Experiment 2}

The volume of the co-incubation medium appeared not to affect the results of pig IVF, as is shown in Tables 3 and 4 . However, if we compare the percentages of monospermic oocytes in every group as the number of monospermic oocytes in relation to the number of fertilised oocytes (rather than as the number of monospermic oocytes in relation to the total number of healthy mature oocytes) the percentage was significantly higher $(p<0.05)$ with $0.4 \mathrm{ml}$ of medium (78\%) than with $2 \mathrm{ml}(57.5 \%)$. The mean number of spermatozoa per oocyte $(p<0.05)$ and the
Table 3 Influence of the volume of co-incubation medium during IVF on the penetrability of in vivo matured oocytes

\begin{tabular}{lllll}
\hline $\begin{array}{l}\text { Medium } \\
\text { volume } \\
(\mathrm{ml})\end{array}$ & $\begin{array}{l}\text { Oocytes } \\
\text { recovered }\end{array}$ & $\begin{array}{l}\text { Healthy } \\
\text { mature } \\
\text { oocytes } \\
(\%)\end{array}$ & $\begin{array}{l}\text { Fertilised } \\
\text { oocytes } \\
(\%)\end{array}$ & \begin{tabular}{l} 
Fertilisation $_{\text {range }^{a}(\%)}$ \\
\hline 0.4
\end{tabular} \\
\hline 2 & 136 & $115(84.6)$ & $64(55.6)$ & $52-77$ \\
\hline
\end{tabular}

${ }^{a}$ Variation in the percentage of fertilisation in five trials.

percentage of dispermic oocytes $(p<0.01)$ were significantly lower with $0.4 \mathrm{ml}$ than with $2 \mathrm{ml}$. The percentage of activated oocytes ranged from $0.9 \%$ to $1.7 \%$ in both groups.

\section{Discussion}

The presence of cumulus cells and intercellular matrix in the co-incubation medium increased the fertilisation and monospermy rates during IVF in pigs. Cumulus cells could exert their effect by reducing spermatozoa-oocyte collisions (Barros \& Yanagimachi, 1972) or by improving the viability of the oocytes in the culture by continued synthesis of hyaluronic acid (Yang \& Yanagimachi, 1989; Sato et al., 1990). Oviductal glycoproteins which bind to the zona pellucida of newly ovulated pig eggs (Brown \& Cheng, 1986) improve porcine IVF, including a reduction in the incidence of polyspermy (Nagai \& Moor, 1990). These glycoproteins could reduce the simultaneous penetration of the zona pellucida or the enveloping cumulus matrix by two or more spermatozoa, thereby reducing the chances for polyspermic fertilisation (Hunter, 1991). These glycoproteins might also enter the perivitelline space (Verhage \& Fazleabas, 1990) and facilitate a more synchronous exocytosis of cortical granule contents or increase physiological 
Table 4 Influence of the volume of medium used during co-incubation on the number of spermatozoa observed in the ooplasm

\begin{tabular}{|c|c|c|c|c|c|c|}
\hline \multirow{2}{*}{$\begin{array}{l}\text { Medium } \\
\text { volume } \\
\text { (ml) }\end{array}$} & \multirow{2}{*}{$\begin{array}{l}\text { Healthy } \\
\text { mature } \\
\text { oocytes }\end{array}$} & \multirow{2}{*}{$\begin{array}{l}\mathrm{Spz} / \mathrm{oo}^{a} \\
(x \pm \mathrm{SEM})\end{array}$} & \multirow{2}{*}{$\begin{array}{l}\text { Monospermic } \\
\text { oocytes }^{b}(\%)\end{array}$} & \multicolumn{3}{|c|}{ Polyspermic oocytes (\%) } \\
\hline & & & & $2 \mathrm{spz}$ & $3 \mathrm{spz}$ & $>3 \mathrm{spz}$ \\
\hline 0.4 & 115 & $1.28 \pm 0.07^{c}$ & $50(43.5)$ & $11(9.6)^{d}$ & $2(1.7)$ & $1(0.9)$ \\
\hline 2 & 111 & $1.50 \pm 0.06^{c}$ & $42(37.8)$ & $26(23.4)^{d}$ & $4(3.6)$ & $1(0.9)$ \\
\hline
\end{tabular}

Spz, spermatozoa; oo, oocyte.

a Relative to number of fertilised oocytes.

${ }^{b}$ As a percentage of the total number of healthy mature oocytes.

${ }^{c}$ Groups with the same superscript are different $(p<0.05)$.

${ }^{d}$ Groups with the same superscript column are different $(p<0.01)$.

responses of the zona pellucida to cortical granule material (Barros \& Yanagimachi, 1971; Yang \& Yanagimachi, 1989). Since all our oocytes were recovered from the oviducts, the oviductal glycoproteins were always present. Our comparatively low rates of polyspermy are consistent with all previous hypotheses regarding the effects of oviduct glycoproteins on the zona pellucida. The glycoproteins might also stabilise the sperm plasma membrane and reduce the number of spermatozoa capacitated simultaneously, as hypothesized by Hunter (1991).

Alternatively, cumulus cells might have receptors for the oviductal glycoproteins or other oviductal factor(s), or the oviductal secretions might influence the intercellular matrix. This might also explain the different appearance of the cumulus recovered from the oviduct compared with that from the follicular oocytes just before ovulation (Braden, 1962). Binding of the glycoproteins could facilitate the entry of spermatozoa into the cumulus and explain the higher rates of fertilisation in our study and that of Kikuchi et al. (1991). On the other hand, the spermatozoa could induce some change which delayed or made more difficult the entry of other spermatozoa, perhaps by means of the enzymes released during the acrosome reaction, facilitating monospermic penetration. Although the presence of cumulus cells might also benefit capacitation or the acrosome reaction (Gwatkin et al., 1972; Yanagimachi, 1988), such an effect does not explain the reduced rate of polyspermy we observed.

Different workers have used $2 \mathrm{ml}, 0.4 \mathrm{ml}, 0.2 \mathrm{ml}$ and $0.1 \mathrm{ml}$ for porcine IVF, with variable results, but they have not studied the effects of changing the volume of medium. Our results show no differences in fertilisation rates with $0.4 \mathrm{ml}$ or $2 \mathrm{ml}$ of medium. Although some parameters related to monospermy appeared to be improved by using the reduced volume, we do not have enough data to explain the mechanism.

In conclusion, the continued presence of cumulus cells and the intercellular matrix increased the rates of fertilisation and monospermy in porcine IVF. The volume of gamete co-incubation medium seemed to influence some parameters related to monospermy. This volume effect should be studied further.

\section{Acknowledgement}

We thank Trish Berger for her helpful comments on the manuscript. This study was in part supported by the Comision Interministerial de Ciencia y Tecnologia (CYCIT), (AGF 92-0521).

\section{References}

Barros, C. \& Yanagimachi, R. (1971). Induction of zona reaction in golden hamster eggs by cortical granule material. Nature 233, 268-9.

Barros, C. \& Yanagimachi, R. (1972). Polyspermy-preventing mechanisms in the golden hamster egg. J. Exp. Zool. 180, 251-66.

Braden, A.W.H. (1962). Spermatozoon penetration and fertilization in the mouse. Symp. Genet. Biol. Ital. (Pavia) 9, 1-8.

Brown, C.R. \& Cheng, W.T.K. (1986). Changes in composition of the porcine zona pellucida during development of the oocyte to the 2- to 4-cell embryo. J. Embryol. Exp. Morphol. 92, 183-91.

Chang, M.C. (1952). Fertilizability of rabbit ova and the effects of temperature in vitro on their subsequent fertilization and activation in vivo. J. Exp. Zool. 121, 351-81.

Chang, M.C., Hanada, A. \& Hunt, D.M. (1971). Fertilization of denuded rabbit eggs in vitro by sperm recovered from the uterus or vagina. Nature 232, 343-4.

Cheng, W.T.K., Moor, R.M. \& Polge, C. (1986). In vitro fertilization of pig and sheep oocytes matured in vivo and in vitro. Theriogenology 25, 146.

Coy, P. (1992). Fecundación in vitro en la especie porcina: influencia de diferentes condiciones de cocultivo. Murcia: Secretariado de Publicaciones Universidad de Murcia. ISBN: 84-7684-277-5.

Coy, P., Martínez, E., Ruiz, S., Vazquez, J.M., Roca, J., Matas, C. \& Pellicer, M.T. (1993a). In vitro fertilization of pig 
oocytes after different coincubation intervals. Theriogenology. 39: 1201-1208.

Coy, P., Martínez, E., Ruiz, S., Vazquez, J.M., Roca, J. \& Matas, C. (1993b). Sperm concentration influences fertilization and male pronuclear formation in vitro in pigs. Theriogenology (in press).

Cross, P.C. \& Brinster, R.L. (1970). In vitro development of mouse oocytes. Biol. Reprod. 3, 298-307.

Fraser, L.R., Danderkar, P.V. \& Vaidya, R.A. (1971). In vitro fertilization of tubal rabbit ova partially or totally denuded of follicular cells. Biol. Reprod. 4, 229-33.

Fukui, Y. \& Ono, H. (1989). Effects of sera, hormones and granulosa cells added to culture medium for in vitro maturation, fertilization, cleavage and development of bovine oocytes. J. Reprod. Fert. 86, 501-6.

Gwatkin, R.B.L., Andersen, O.F. \& Hutchison, C.F. (1972). Capacitation of hamster spermatozoa in vitro; the role of cumulus components. J. Reprod. Fert. 30, 389-94.

Hunter, R.H.F. (1991). Oviduct function in pigs, with particular reference to the pathological condition of polyspermy. Mol. Reprod. Dev. 29, 385-91.

Kikuchi, K., Nagai, T. \& Motlik, J. (1991). Effect of follicle cells on in vitro fertilization of pig follicular oocytes. Theriogenology 35, 225.

Martín, S., Perez, C. \& Alias, E. (1983). Fertility results by using boar semen diluted 1:10 after 5 days' storage. In: 34 Reunión Anual de FEZ, Madrid, vol. 2, p. 755.

Mattioli, M., Galeati, G. \& Seren, E. (1988). Effect of follicle somatic cells during pig oocyte maturation on egg penetrability and male pronucleus formation. Gamete Res. 20, 177-83.

Mattioli, M., Bacci, M.L., Galeati, G. \& Seren, E. (1989). Developmental competence of pig oocytes matured and fertilized in vitro. Theriogenology 31, 1201-7.

Miyamoto, H. \& Chang, M.C. (1972). Fertilization in vitro of mouse and hamster eggs after the removal of follicular cells. J. Reprod. Fert. 30, 309-12.

Nagai, T. \& Moor, R.M. (1990). Effect of oviduct cells on the incidence of polyspermy in pig eggs fertilized in vitro. Mol. Reprod. Dev. 26, 377-82.

Niwa, K. \& Chang, M.C. (1974). Various conditions for the fertilization of rat eggs in vitro. Biol. Reprod. 11, 463-9.

Park, C.S. \& Pursel, V.G. (1991). In vitro fertilization of pig ova. J. Anim. Sci. 69, 404.

Sato, E., Miyamoto, H. \& Koide, S.S. (1990). Glycosaminoglycans in porcine follicular fluid promoting viability of oocytes in culture. Mol. Reprod. Dev. 26, 391-7.

Shioya, Y., Kuwayama, M., Fukushima, M., Iwasaki, S. \& Hanada, A. (1988) In vitro fertilization and cleavage capability of bovine follicular oocytes classified by cumulus cells and matured in vitro. Theriogenology 30, 489-96.

Vázquez, J.M. (1991). Fecundacion in vitro en la especie porcina: análisis de la capacitación y reacción acrosómica. Murcia: Secretariado de Publicaciones Universidad de Murcia. ISBN: 84-7684-240-6.

Verhage, H.G. \& Fazleabas, A.T. (1990). Steroid-dependent oviduct secretions in the primate. In: Biology of the Mammalian Oviduct, ed. H. Croxato. Santiago.

Yanagimachi, R. (1981). Mechanisms of fertilization in mammals. In: L. Mastroianni, Jr., J.D. Biggers (eds.): Fertilization and Embryonic Development In Vitro, ed. L. Mastroianni Jr \& J.D. Biggers, pp. 81-182. New York: Plenum Press.

Yanagimachi, R. (1988). Mammalian fertilization. In: The Physiology of Reproduction, ed. E. Knobil \& J. Neill, pp. 135-85. New York: Raven Press.

Yang, C.H. \& Yanagimachi, R. (1989). Differences between mature ovarian and oviductal oocytes: a study using the golden hamster. Hum. Reprod. 4(1), 63-71. 